\title{
PERANCANGAN SISTEM ENTERPRISE RESOURCE PLANNING MODUL PAYROLL BERBASIS ODOO 8 DENGAN METODE RAPID APPLICATION DEVELOPMENT PADA PT.XYZ
}

\section{ENTERPRISE RESOURCE PLANNING SYSTEM DESIGN PAYROLL MODULE BASED ON ODOO 8 WITH RAPID APPLICATION DEVELOPMENT METHODOLOGY IN PT. XYZ}

\author{
${ }^{1}$ Ginanjar Dewi Girang, ${ }^{2}$ Rachmadita Andreswari ${ }^{3}$ Umar Yunan K.S.H. \\ ${ }^{1,2,3}$ Program Studi Sistem Informasi, Fakultas Rekayasa Industri, Telkom University \\ 19inanjardewi95@gmail.com, ${ }^{2}$ andreswari@gmail.com, ${ }^{3}$ umaryunan@telkomuniversity.ac.id
}

\begin{abstract}
Abstrak-PT. XYZ merupakan perusahaan nasional yang bergerak di bidang manufaktur dan distribusi minuman. Hingga tahun 2016 PT. XYZ telah memiliki karyawan 550 orang, terdiri atas karyawan tetap, dan karyawan harian. Dengan jumlah karyawan meningkat setiap tahunnya, PT. XYZ membutuhkan pengelolaan Sumber Daya Manusia (SDM) yang baik untuk meningkatkan kinerja karyawan. Salah satu faktor kenaikan kinerja karyawan yaitu melalui sistem penggajian. Proses penggajian PT. XYZ dilakukan satu bulan sekali dengan pemberian gaji yang berbeda pada setiap karyawan sesuai dengan gaji dan intensif yang di dapat. Adapun pencatatan penggajian menggunakan komponen gaji pokok, bonus, dan potongan. Terdapat permasalahan pada proses penggajian PT. XYZ yaitu adanya komponen yang salah terinputkan dan berakibat pada perhitungan pengajian yang salah, sehingga menyebabkan pemberian gaji yang terlambat. Untuk menyikapi hal tersebut, sistem Enterprise Resource Planning (ERP) menjadi solusi untuk proses penggajian pada PT. XYZ. Melalui penggunaan sistem ERP, dimungkinkan integrasi melalui satu database yang memudahkan perusahaan dalam berbagi data. Salah satu software ERP yang dapat digunakan untuk mendukung proses penggajian yaitu Odoo 8. Odoo merupakan software ERP yang bersifat open source, dapat di kustomisasi sesuai dengan kebutuhan user \& proses bisnis dari perusahaan yang menerapkan Odoo. Pada penelitian ini, perancangan sistem ERP untuk PT.XYZ menggunakan metode pengembangan sistem Rapid Application Development (RAD) yang memiliki kelebihan diantaranya untuk menghemat waktu dan biaya selama penelitian. Perancangan sistem ERP untuk proses penggajian pada PT.XYZ dipercaya dapat memberikan dampak pada kemajuan perusahaan dalam mendukung proses penggajian dengan tepat, cepat, dan efesien sesuai dengan kebutuhan perusahaan serta adanya laporan penggajian yang detail.
\end{abstract}

Kata kunci: Sumber Daya Manusia, Penggajian, Enterprise Resource Planning, Odoo, Rapid Application Development.

$\begin{array}{ll}\text { Sejarah artikel } & \\ \text { Diterima redaksi: } & : 24 \text { Mei } 2017 \\ \text { Revisi akhir } & : \text { 04 Juli } 2017 \\ \text { Diterbitkan online } & : \text { 19 Desember } 2017\end{array}$

Abstract-PT. XYZ is a national company engaged in the Manufacturing and Distribution of Drinks. Until 2016 PT. XYZ already has 550 employees consisting of permanent employees, and daily employees. PT. XYZ requires a good Human Resource Management to improve performance of employee. One of factor to improve performance employee is from payroll. Payroll process in PT. XYZ is going for once of a month with a different salary of each employee according by salary structure and intensive. The components of payroll are basic payroll, allowance, and deduction. On the other hand, PT. $\mathrm{XYZ}$ has a problem in payroll process. It has an incorrect component, incorrect the result, and a late salary distribution. Enterprise Resource Planning (ERP) is one of solution for payroll processing at PT. XYZ. By using ERP is allows the company to integrated with one of database that can to share data. One of ERP software that can be used to support the payroll process is Odoo 8. Odoo is an open source ERP system, that can be customized according to the needs of the user and the company that will implement odoo. A design ERP system for PT.XYZ is using by Rapid Application Development method which has an advantages such as time saving, and reduced cost during ongoing research. The result of design an ERP system for payroll process at PT. XYZ is to provide impact progress of company to support a payroll process with precise, fast and to have a detailing report for report payslip.

Keywords: Human Resource Management, Payroll, Enterprise Resource Planning, Odoo, Rapid Application Development.

\section{PENDAHULUAN}

Pada era globalisasi, penggunaan sistem informasi banyak digunakan oleh perusahaan untuk menunjang jalannya proses bisnis di perusahaan. Sistem informasi merupakan komponen - komponen yang saling berhubungan dan bekerjasama untuk mengumpulkan, memproses, menyimpan, dan menyebarkan informasi untuk mendukung pengambilan keputusan, koordinasi, pengendalian, dan untuk memberikan gambaran aktivitas didalam perusahaan [1]. Penerapan sistem informasi dapat meningkatkan efisiensi di bagian operasional, dalam hal membantu mengurangi waktu operasional. 
Selain itu, sistem informasi dapat menghasilkan informasi akurat yang dapat digunakan oleh manajer untuk pengambilan keputusan. Sistem informasi diimplementasikan dalam sebuah organisasi dimulai dari tingkat yang sederhana sampai kompleks, seperti enterprise. Implementasi sistem informasi yang berbasis enterprise ini sering kali disebut sebagai Enterprise Resource Planning (ERP) [2]. ERP memiliki 3 modul utama yaitu modul finance, distribution dan manufacturing, serta Human Resource [3]. Modul Human Resource (sumber daya manusia) merupakan modul yang bertanggung jawab untuk mengatur dan mengelola sumber daya manusia yang dimiliki oleh suatu perusahaan meliputi data karyawan, penilaian karyawan, pengajian karyawan, pelatihan karyawan, dan pengembangan karyawan.

Perancangan konsep ERP membutuhkan sebuah software sebagai pendukung. Salah satu sofware ERP yang saat ini banyak digunakan adalah Odoo 8 . Odoo 8 merupakan salah satu software yang bersifat open source dan memiliki beberapa modul, salah satunya modul payroll. Fungsi modul ini adalah untuk mendukung proses yang terdapat pada fungsi penggajian, seperti pembuatan slip gaji. Slip gaji merupakan laporan hasil akhir yang didapat pada modul payroll. Adapun fungsinya adalah untuk memuat data - data yang diperlukan pada perhitungan kompenen gaji yang hasilnya sesuai dengan perhitungan struktur gaji.

PT. XYZ merupakan perusahaan nasional yang bergerak di bidang manufaktur dan distribusi minuman. PT. XYZ mulai berdiri pada tahun 2004 dan berproduksi pada tahun 2005 dengan produk minuman berbahan dasar teh yang memiliki kemasan gelas dan botol. Hingga tahun 2016, PT. XYZ telah memiliki 550 orang karyawan yang terdiri atas karyawan tetap dan karyawan harian. Dengan jumlah karyawan yang setiap tahun meningkat, PT. XYZ membutuhkan pengelolaan SDM yang baik yang dapat membuat kinerja karyawan menjadi semakin baik. Salah satu cara manajemen untuk meningkatkan prestasi kerja, meningkatkan kepuasan dan kinerja karyawan dengan melalui kompensasi [4].

Proses Penggajian atau pemberian kompensasi pada PT. XYZ sendiri dilakukan satu bulan sekali untuk karyawan tetap dan karyawan harian. Jumlah gaji yang diberikan pada setiap pegawai berbeda, sesuai dengan gaji dan intensif yang didapatkannya. Adapun pencatatan penggajian yang digunakan memiliki komponen seperti absensi, lembur, dan potongan. Untuk proses sistem perhitungan penggajian yang digunakan sekarang menggunakan aplikasi spreadsheet yang populer yaitu MS. Excel. Namun, pada proses perhitungan penggajian sering ditemukan adanya kesalahan yang disebabkan human error seperti kesalahan input komponen, melakukan perubahan langsung field secara bersamaan, serta tidak adanya notifikasi pada aplikasi MS. Excel ketika user melakukan kesalahan. Hal tersebut menyebabkan proses perhitungan memiliki waktu yang lama, dan juga tidak adanya database yang terpusat sebagai sarana penyimpanan. Adanya permasalahan tersebut berakibat pada pelaporan slip gaji karyawan yang tidak sesuai dengan gaji karyawan yang seharusnya diterima dan keterlambatan pembagian penggajian.

Rapid Application Development (RAD) yaitu suatu pendekatan berorientasi objek terhadap pengembangan sistem yang mencakup suatu metode pengembangan serta perangkat- perangkat dimana memiliki kelebihan dapat mempersingkat waktu yang biasanya diperlukan dalam siklus pengembangan sistem tradisional antara perancangan dan penerapan suatu sistem informasi [5]. Metode RAD digunakan dalam penelitian ini untuk melakukan pengembangan sistem informasi untuk menyelesaikan masalah yang dihadapi di PT. XYZ. Masalah yang terjadi pada proses penggajian PT. XYZ dapat dirumuskan dengan bagaimana proses bisnis pada Departemen Human Resource Development bagian penggajian dan bagaimana menyesuaikan sistem payroll yang dapat menyusun laporan slip gaji yang detail menampilkan total beserta komponen penggajian sebagai solusi permasalahan yang ada. Berdasarkan perumusan masalah tersebut, maka penelitian ini bertujuan untuk mendapatkan gambaran proses bisnis pada departemen Human Resource Development yang sedang berjalan dan membangun rancangan integrasi modul payroll dengan modul employee management dan modul recruitment. Adapun manfaat yang diperoleh dari penelitian ini yaitu merancang sistem informasi berbasis ERP untuk modul payroll, membantu berjalannya proses bisnis pada departemen Human Resource bagian payroll dalam mengelola informasi bersifat real time, dan adanya laporan slip gaji karyawan yang akurat dan detail menampilkan total beserta komponen penggajian untuk setiap karyawan.

\section{STUDI LITERATUR}

\section{A. Enterprise Resource Planning}

Enterprise Resource Planning (ERP) adalah sebuah sistem yang membantu untuk mengatur proses bisnis seperti marketing, produksi, pembelian, dan accounting dalam suatu kesatuan yang terintegrasi [6]. Enterprise Resource Planning (ERP) merupakan suatu sistem yang membantu proses bisnis untuk saling terintegrasi satu sama lain, dengan data penyimpanan terpusat dan memiliki tujuan yaitu untuk pencapaian alur informasi perusahaan yang jelas. Adapun kelebihan ERP antara lain dapat mengintegrasikan seluruh fungsi yang ada di perusahaan sehingga tercipta komunikasi, produktivitas, dan efisiensi yang lebih baik dari sebelumnya, dan mampu menyediakan data yang bersifat real-time untuk semua bagian [7].

\section{B. Manajemen Sumber Daya Manusia}

Manajemen Sumber Daya Manusia (MSDM) merupakan suatu ilmu yang digunakan untuk mengatur, mengelola tenaga kerja untuk membantu mewujudkan tujuan dari perusahaan. Dimana perilaku, prestasi tenaga kerja sangat berpengaruh untuk jalannya MSDM. Sumber daya manusia (SDM) merupakan salah satu faktor yang sangat penting dalam suatu perusahaan di samping faktor yang lain seperti modal. Oleh karena itu, SDM harus dikelola dengan baik untuk mengingkatkan efektivitas dan efisiensi organisasi, sebagai salah satu fungsi dalam perusahaan yang dikenal dengan manajemen sumber daya manusia [8]. Adapun fungsi dari Manajemen Sumber Daya Manusia berdasarkan Bangun [9] diantaranya seperti pengadaan sumber daya manusia, pengembangan sumber daya manusia, kompensasi, melakukan integrasi, dan pemeliharaan sumber daya manusia.

\section{Payroll}

Payroll (gaji pegawai) adalah pengeluaran yang diperlukan untuk membayar karyawan dan pajak - pajak penghasilan karyawan yang menjadi tanggungan perusahaan. Payroll adalah jumlah total yang dari seorang majikan/pimpinan kepada karyawan yang 
dinyatakan dalam kontrak kerja atas jasa - jasa yang telah mereka berikan dalam satu periode tertentu, biasanya perbulan atau pertahun [10]. Payroll merupakan total yang dibayarkan kepada karyawan atas jasa - jasa yang mereka berikan selama suatu periode tertentu [11]. Keputusan mengenai pemberian gaji menurut Noe, Gerhart dan Wright [12] dibagi menjadi tiga yaitu:

1. Job Structure

Membedakan gaji berdasarkan posisi pekerjaan yang dijabat.

2. Pay Level

Jumlah rata - rata suatu perusahaan untuk menggaji suatu pekerjaan, penggajian sudah termasuk upah, gaji, dan bonus.

3. Pay Structure

Kebijakan pembayaran gaji berdasarkan Job Stucture \& Pay Level untuk membantu organisasi mencapai tujuan yang berhubungan dengan motivasi karyawan, pengendalian biaya, dan kemampuan untuk mempertahankan sumber daya manusia.

\section{Undang - Undang}

Undang - undang mengenai penggajian terbagi atas undang undang ketenagakerjaan yaitu pada pasal 88 yang menjelaskan bahwa pemerintah menetapkan pengupahan yang melindungi pekerja/buruh, undang-undang pajak penghasilan. Pasal 21 menyatakan bahwa pajak atas penghasilan berupa gaji, upah, honorarium, tunjangan, dan pembayaran lain dengan nama dan dalam bentuk apa pun sehubungan dengan pekerjaan atau jabatan, jasa, dan kegiatan yang dilakukan oleh orang pribadi, sebegaimananya yang dimaksud dalam Pasal 21 Undang - undang No. 36 Tahun 2008 [13], dan undang-undang badan penyelenggara jaminan social yang merupakan lembaga yang dibentuk untuk menyelenggarakan Program Jaminan Sosial di Indonesia.

\section{E. Odoo}

Odoo merupakan aplikasi ERP yang memiliki desain modern dan lengkap yang didistribusikan secara open source. Aplikasi ERP ini memiliki berbagai program aplikasi bisnis termasuk Sales, CRM, Project Management, Warehouse Management, Manufacturing, Finance and Accounting, Human Resource dan lain sebagainya [14]. Odoo merupakan salah satu aplikasi ERP yang bersifat open source dan menggunakan bahasa pemograman Phyton. Sebelumnya, Odoo bernama TinyERP yang berasal dari sebuah perusahaan yang bernama Tiny SPRL di Belgia lalu berubah menjadi OpenERP dan dari tahun 2014 - sekarang menjadi Odoo. Aplikasi Odoo dapat di kustomisasi sesuai dengan kebutuhan user dan proses bisnis dari perusahaan yang menerapkan aplikasi ini.

\section{F. Modul Payroll pada Odoo}

Modul Payroll adalah modul pengajian umum yang disediakan oleh Odoo. Modul ini mendukung proses-proses penggajian umum mulai dari pembuatan kontrak kerja, pembuatan aturan dan struktur penggajian, perhitugan gaji hingga pembuatan slip gaji karyawan. Kontrak kerja yang dibuat per karyawan memuat masa berlaku kontrak, jabatan karyawan, gaji pokok dan fasilitas yang berhak diterima, struktur gaji yang digunakan, serta ijin kerja untuk karyawan yang bersangkutan [15]. Penggajian didefinisikan sebagai metode pelaporan penggajian karyawan dalam organisasi. Proses ini terdiri dari perhitungan gaji dan pemotongan pajak dari karyawan, pelaporan pensiun dan pembayaran gaji kepada karyawan. Hal ini juga dapat disebut sebagai suatu kegiatan akun yang melakukan administrasi gaji karyawan dalam organisasi. Pelaporan penggajian karyawan bukanlah tugas yang sederhana, Human Resource dan departemen lain bersama-sama untuk menghitung dan memberikan gaji kepada karyawan. Dengan demikian, manajemen penggajian dapat dibagi lagi menjadi dua sub proses, yaitu akuntansi penggajian dan pelaporan penggajian [16]. Hasil akhir dari payroll adalah payslips yang digunakan sebagai bukti pembayaran gaji terhadap karyawan [17]. Didasarkan pada sumber yang ada, modul Payroll pada Odoo merupakan salah satu modul bagian Human Resource yang berfungsi untuk menghitung gaji / upah yang diterima karyawan disesuaikan dengan kontrak kerja.

\section{G. Metode Rapid Application Development}

Metode Rapid Application Development (RAD) adalah sebuah metode pengembangan software. Untuk pengimplementasian metode RAD dapat berjalan dengan maksimal, jika developer telah merumuskan kebutuhan dan ruang lingkup pengembangan aplikasi dengan baik. [18]. Adapun fase yang terdapat pada metode RAD di jelaskan pada Gambar 1 [19].

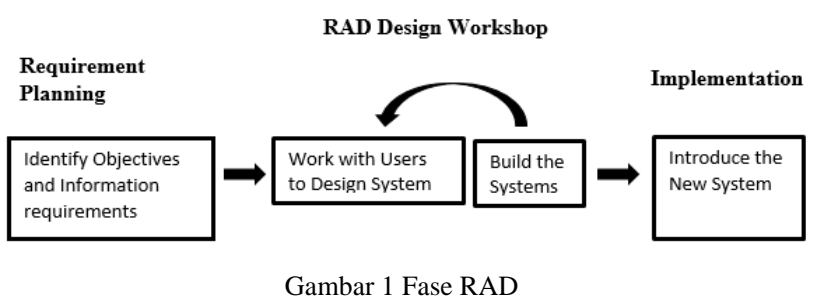

III. METODOLOGI PENELITIAN

\section{A. Model Konseptual}

Kerangka untuk membangun model konseptual untuk penelitian Sistem Informasi dapat menggunakan paradigma design science dan behavior science [20] [21]. Framework penelitian untuk penelitian ini diilustrasikan seperti pada Gambar 2. Berikut merupakan penjelasan mengenai modul konseptual pada Gambar 2.

1. Pada bagian lingkungan, permasalahan yang ada pada PT. XYZ menjadi objek pada penelitian yang mengangkat permasalahan mengenai belum adanya integrasi Departemen Human Resource Development. Aktor yang terlibat dalam ruang lingkup permasalahan yaitu General Manager dan Departemen Human Resource. Dokumen yang diperlukan berupa standar operasional prosedur penggajian PT. XYZ dijadikan sebagai bahan informasi dalam penelitian ini. Dengan menggunakan teknologi berupa software odoo berbasis web based.

2. Dasar ilmu yang digunakan pada penelitian ini terdiri atas dua bagian yaitu konsep dan metode. Untuk konsep membutuhkan pembahasan mengenai Enterprise Resource Planning dan modul Human Resource bagian payroll. Dan metode yang digunakan yaitu Metode Rapid Application Development.

3. Output yang dihasilkan dalam penelitian ini adalah sebuah perancangan sistem ERP modul Human Resource bagian payroll pada kasus di PT. XYZ dengan menggunakan user acceptance testing, analisis dan simulasi digunakan sebagai bahan evaluasi perancangan ERP tersebut. Evaluasi yang 
diterima kemudian menjadi bahan perancangan sistem ERP yang dapat digunakan perusahaan jika ingin mengimplementasikan sistem tersebut.

\section{B. Sistematika Penelitian}

Sistematika penelitian merupakan gambaran dari tahapantahapan yang dilakukan dalam melaksanakan penelitian ini. Proses penerapan Odoo menggunakan metode Rapid Application Development (RAD) dengan beberapa fase yaitu, identification, fase requirement planning, $\mathrm{RAD}$ design workshop, dan implementation

1. Fase identification

Fase identification adalah fase untuk mengidentifikasi permasalahan yang diangkat dalam penelitian. Hal pertama yang dilakukan adalah melakukan identifikasi terhadap latar belakang dari permasalahan. Proses identifikasi permasalahan didasarkan pada dua studi, yaitu studi literature dan studi lapangan. Studi literatur bersumber pada buku referensi dan jurnal. Studi lapangan bersumber dari hasil observasi dan wawancara dengan pihak perusahaan. Selanjutnya dibuat rumusan masalah, serta batasan masalah yang akan dibahas dalam penelitian. Setelah itu menentukan tujuan dari penelitian. Untuk penelitian ini membahas perancangan ERP untuk modul Human Resource pada bagian payroll dengan objek PT. $\mathrm{XYZ}$.

\section{2. $\quad$ Fase requirement planning}

Fase requirement planning adalah fase untuk menganalisis dan merencanakan segala kebutuhan yang diperlukan pada sistem penggajian dalam perancangan ERP untuk modul Human Resource pada bagian payroll menggunakan software Odoo. Fase ini dimulai dengan melakukan analisis proses bisnis eksisting pada sistem penggajian yang sedang di laksanakan di PT. XYZ dan juga melakukan analisis pada proses bisnis yang terdapat pada software Odoo modul Human resource bagian Payroll. Selanjutnya dipetakan dengan proses bisnis sistem penggajian pada software Odoo modul Human resource bagian Payroll yang hasilnya sebuah analisa GAP \& FIT. Hasil dari analisa GAP \& FIT adalah sebuah proses bisnis usulan.

\section{Fase RAD design workshop}

Fase ini dimulai dengan proses usulan berupa sebuah perancangan ERP pada departemen Human Resource Development bagian Payroll. Pada tahap ini melibatkan seorang developer. Fase pertama yang dilakukan yaitu seorang developer mendesain proses bisnis perusahaan dengan UML Diagram yang terdiri dari Use Case diagram, dan Activity diagram. Hasil dari UML Diagram tersebut digunakan developer untuk perancangan sistem ERP, adapun peracangan sistem ERP memiliki beberapa tahap yang dilakukan, pertama melakukan konfigurasi, dan yang kedua melakukan kustomisasi. Selanjutnya software odoo yang sudah disesuaikan dengan proses bisnis usulan akan dilakukan pengujian. Diakhir proses akan dilakukan pengujian apakah sesuai dengan proses bisnis usulan jika sesuai akan meneruskan kedalam fase implementation, jika tidak sesuai akan kembali kepada proses bisnis usulan.

\section{Fase implementation}

Fase Implementation merupakan fase dimana sudah sesuainya identifikasi, requirement planning, dan user design sesuai dengan kebutuhan user. Fase ini dilakukan dengan melakukan migrasi data dari perusahaan ke dalam sistem Odoo.

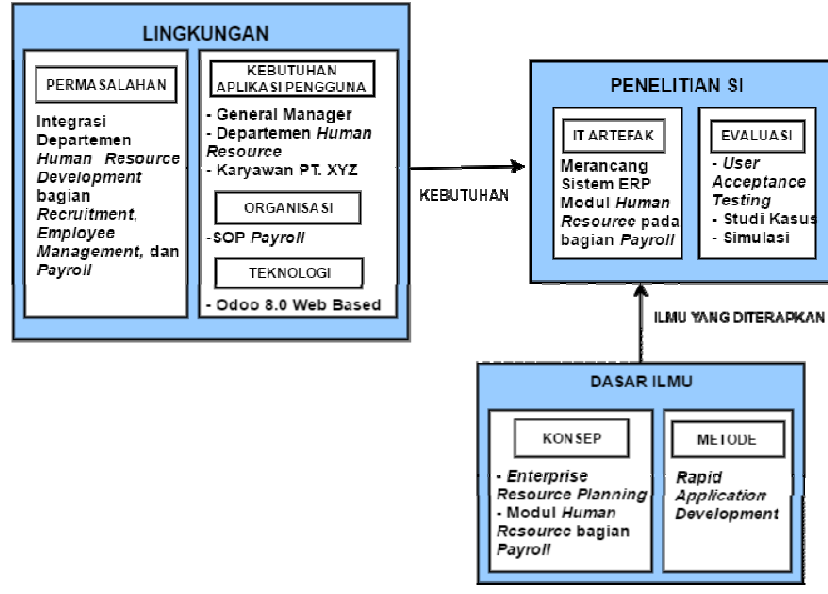

Gambar 2 Framework Penelitian Sistem Informasi

5. Fase penutup

Fase penutup adalah fase terakhir dari proses perancangan sistem ERP software Odoo modul Human Resource bagian payroll. Yang pertama dilakukan pada fase ini adalah menarik kesimpulan dari penelitian yang sudah dilakukan, selanjutnya memberikan saran untuk perusahaan, dan untuk penelitian selanjutnya, dan yang terakhir dari fase ini adalah melakukan publikasi hasil penelitian yang sudah dilakukan.

\section{HASIL DAN PEMBAHASAN}

A. Analisis proses eksisting

PT. XYZ memiliki 4 proses utama pada proses bisnis eksisting pada Departemen Human Resource terdiri atas proses Rekrutmen, Data Karyawan, Kehadiran dan Penggajian dengan stakeholder yang terlibat yaitu Departemen Terkait, Human Resource Manager, Calon Karyawan, Karyawan, Admin Finance \& Accounting, dan Admin Human Resource. Seperti yang diperlihatkan pada Gambar 3. Proses Bisnis Penggajian memiliki 6 proses utama yaitu Proses Gaji Pokok, Proses Tunjangan Tidak Tetap, Proses Peminjaman, Proses Pemotongan Gaji, Proses Tunjangan Hari Raya, dan Proses Pembuatan Laporan Penggajian, dengan stakeholder yang terlibat yaitu Supervisor Departemen, Manager Departemen, Karyawan, Admin Finance \& Accounting, dan Admin Human Resource. Proses bisnis penggajian dapat dilihat pada Gambar 4.

\section{B. Analisis GAP \& FIT}

Analisis GAP \& FIT digunakan untuk mengetahui perbandingan Proses Bisnis eksisting PT.XYZ dengan Proses Bisnis yang dimiliki oleh Odoo. Adapun analisis GAP \& FIT dijelaskan seperti pada Tabel I. Hasil dari Analisis GAP \& FIT akan dijadikan sebagai acuan untuk melakukan analisis proses bisnis usulan untuk bagian penggajian pada PT.XYZ.

\section{Analisis Usulan}

1. Analisis Proses Bisnis Usulan Penggajian

Proses Bisnis Usulan untuk penggajian dilakukan pada proses pengelolaan pelaporan penggajian, dimana pada proses tersebut terdiri atas 5 user yaitu Human Resource, Financial Controller, Finance and Accounting, Bank, dan Karyawan. Proses dimulai 
ketika Bagian Human Resource melakukan perhitungan penggajian, lalu hasil perhitungan penggajian di lakukan konfirmasi, \& validasi oleh Financial Controller jika sudah sesuai akan dilakukan persetujuan, jika tidak sesuai akan dilakukan perhitungan penggajian ulang. Setelah mendapat persetujuan lalu memberi daftar gaji kepada Finance and Accounting untuk dipersiapkan Kas Penggajian, dan daftar perintah transfer ke bank. Selanjutnya Bank menerima laporan penggajian, dan daftar perintah transfer. Proses akhir adalah ketika Bank telah memberi gaji, dan karyawan telah menerimanya

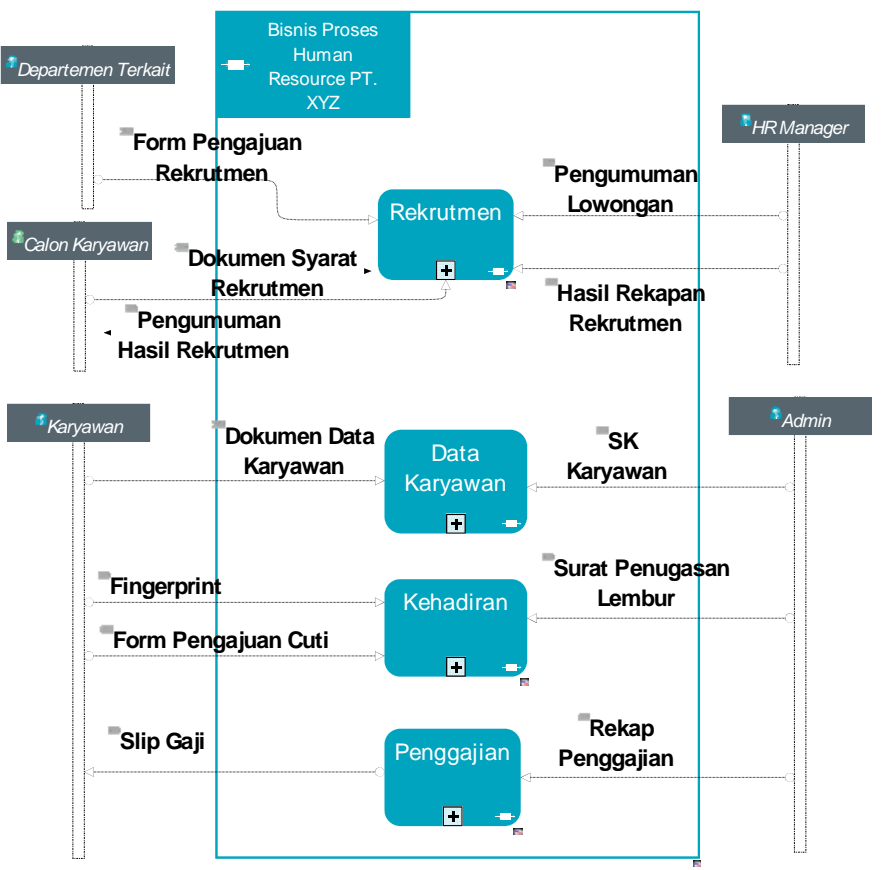

Gambar 3 Proses Utama Departemen Human Resource PT.XYZ

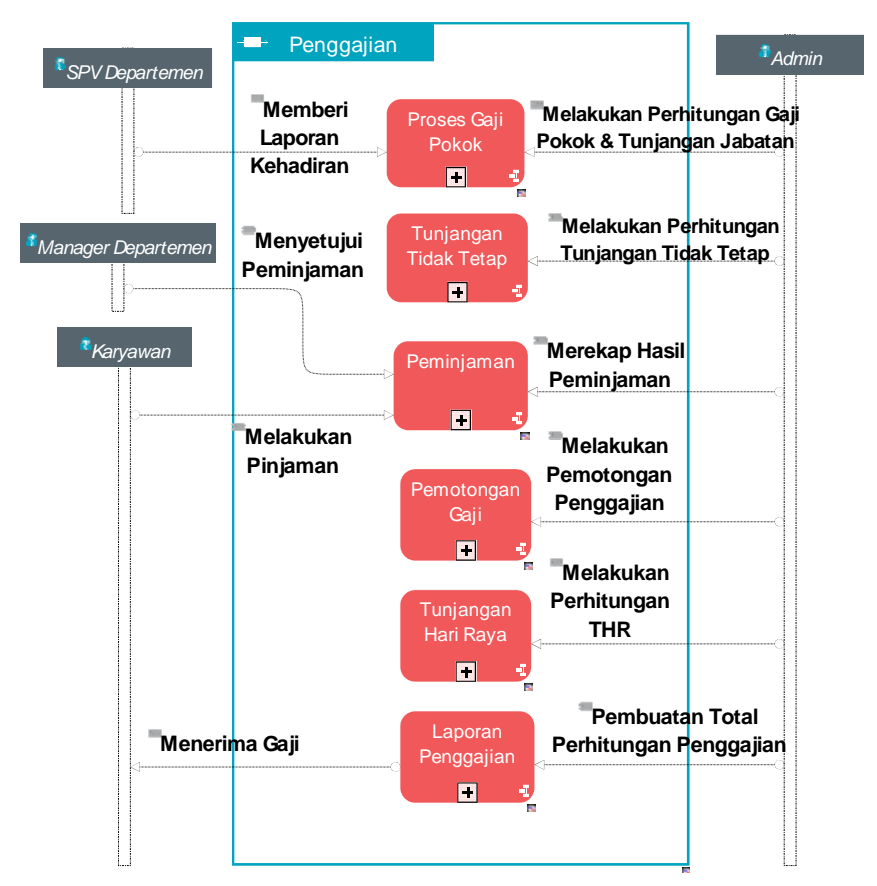

Gambar 4 Proses Bisnis Penggajian
Adapun yang dilakukan pada sistem odoo 8 yaitu pada aktifitas melakukan perhitungan penggajian, melakukan konfirmasi, \& validasi, dan menerima persetujuan. Untuk proses dapat dilihat pada Gambar 5. Pada proses perhitungan penggajian terdapat atas 2 user yang bertanggung jawab yaitu Human Resource Admin, dan Human Resource Manager. Proses dimulai ketika Admin Human Resource melakukan perhitungan penggajian, lalu dikonfirmasi, \& validasi oleh Human Resource Manager. Selanjutnya dilakukan konfirmasi, \& validasi kepada Financial Controller, setelah mendapat persetujuan dilakukan pembuatan laporan untuk diberikan kepada Human Resource Manager, dan Karyawan. Seluruh proses perhitungan penggajian dilakukan pada sistem odoo, seperti yang terlihat pada Gambar 6.

2. Analisis Struktur Penggajian Usulan

Berikut merupakan struktur penggajian usulan yang didasarkan kepada beberapa undang - undang, dan peraturan pemerintah. Adapun struktur penggajian usulan terdiri atas1) gaji/ upah harian; 2) uang lenbur; 3) tunjangan tetap; 4) tunjangan tidak tetap; 5) tunjangan hari raya; 6) pemotongan pajak penghasilan; 7) pemotongan pembayaran iuran jaminan social; dan 8) pemotongan lainnya.

\section{Analisis User Design}

Pada use case diagram ini memiliki 4 aktor yang terlibat, yaitu admin super user yang memiliki kewenangan untuk mengelola user \& data perusahaan. Admin dari bagian Departemen Human Resource Development yang bertugas pada pengelolaan penggajian karyawan, dan Manager Human Resource, dan Financial Controller yang memiliki tugas untuk konfirmasi perhitungan gaji. Berikut merupakan gambaran besar fungsionalitas Odoo Menu Human Resource Modul Payroll dapat dilihat pada Gambar 7. Adapun requirement fungsional dapat dilihat pada Tabel II.

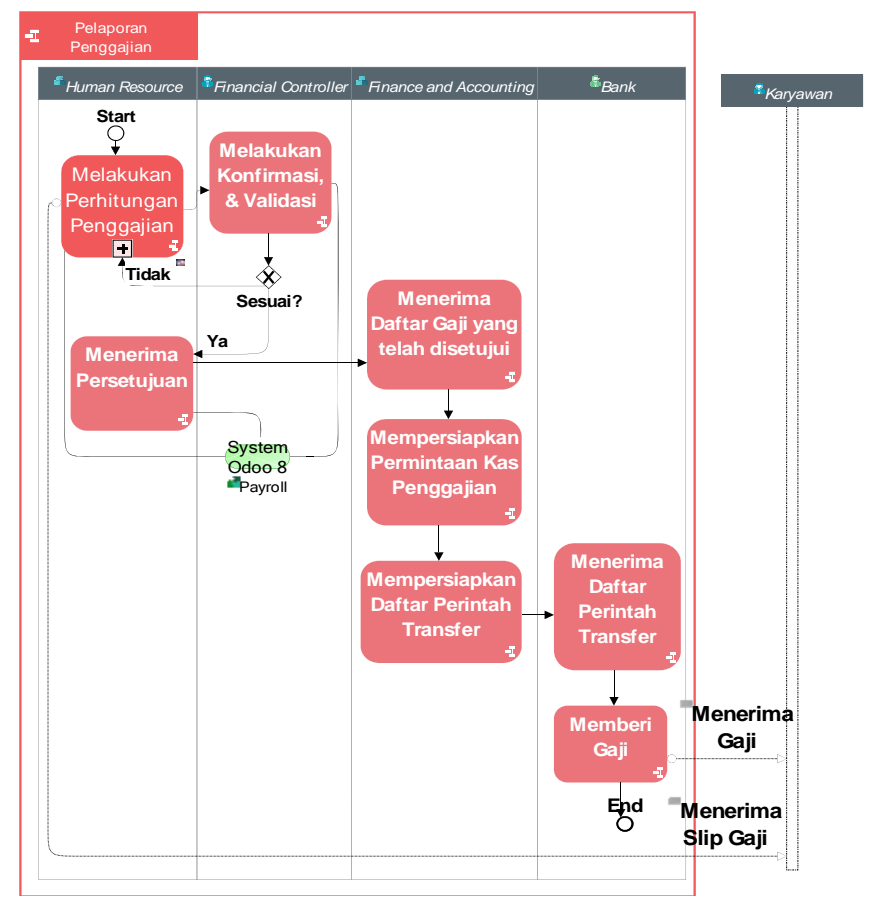

Gambar 5 Pelaporan Penggajian 
TABEL I

ANALISIS GAP \& FIT

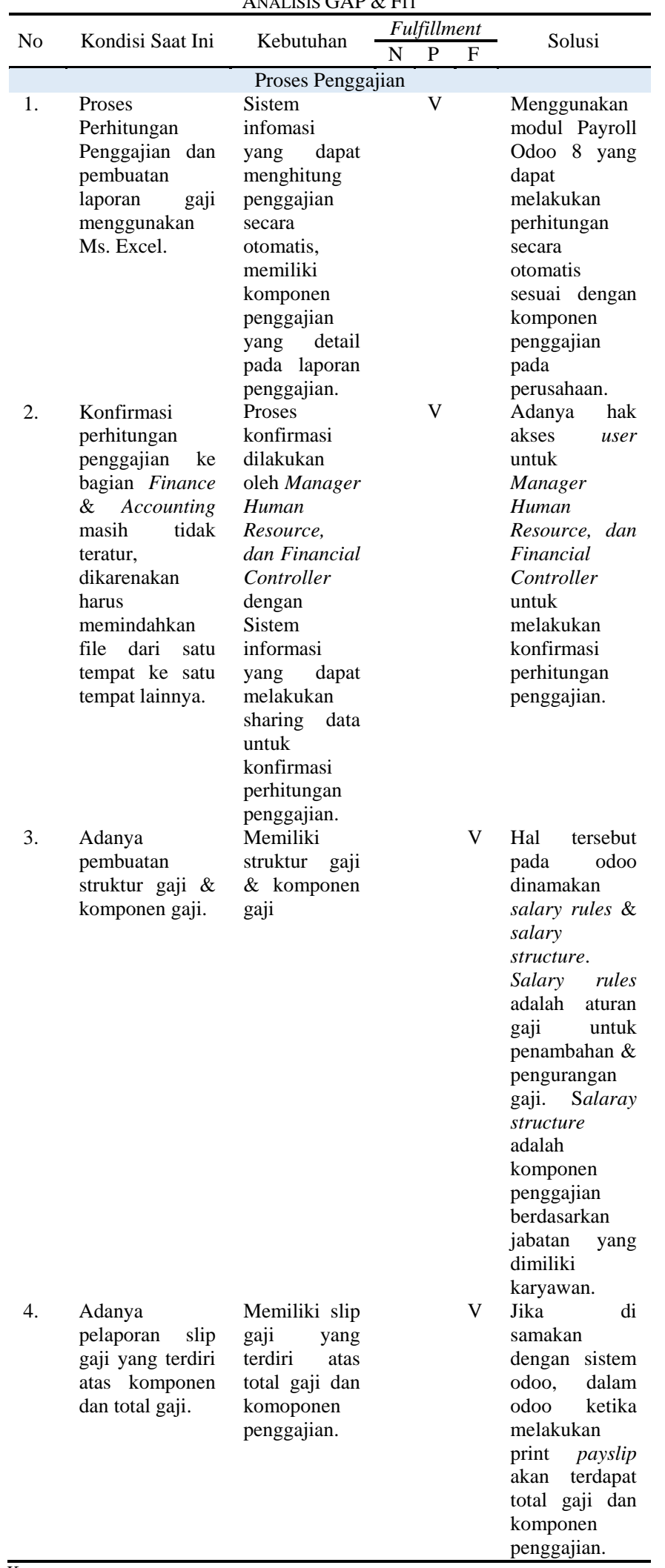

Keterangan:

$\mathrm{N}$ : Kondisi saat ini tidak memenuhi kebutuhan yang disesuaikan dengan Odoo 8.0

P: Kondisi saat ini sebagian memenuhi kebutuhan yang disesuaikan dengan Odoo 8.0

F: Kondisi saat ini sudah memenuhi kebutuhan yang disesuaikan dengan Odoo 8.0

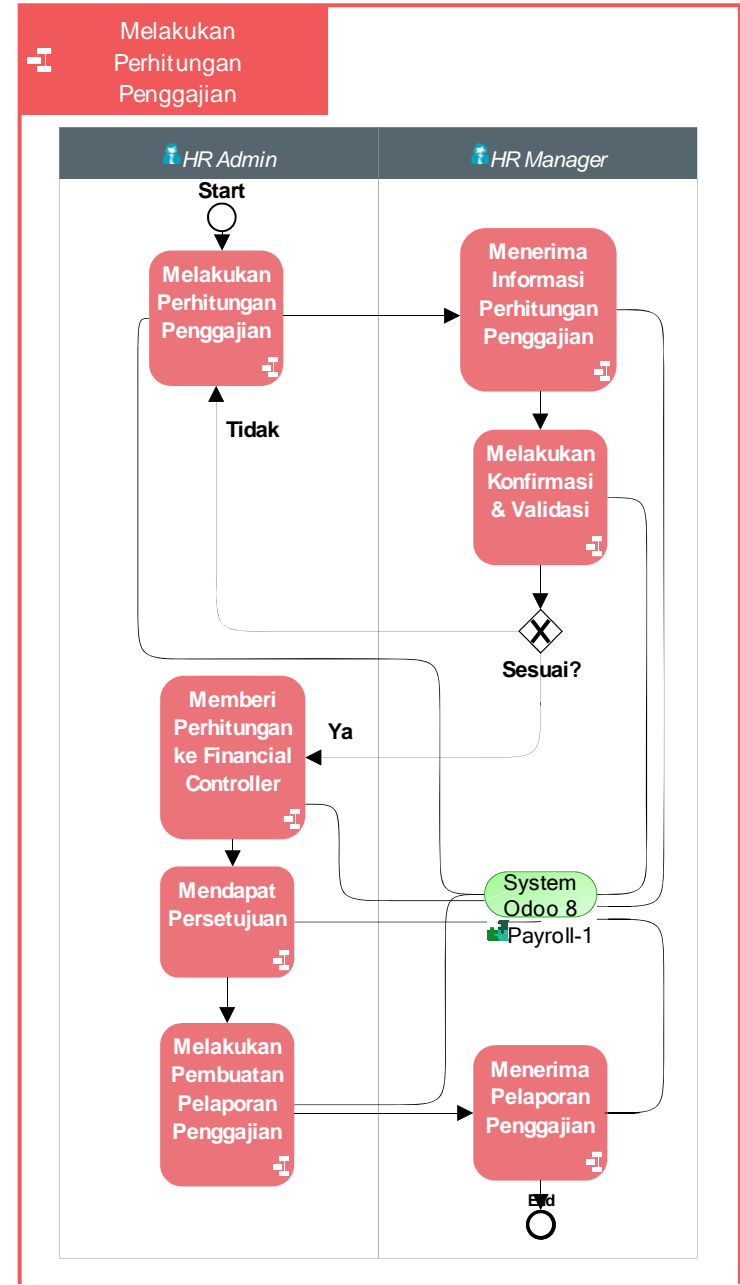

Gambar 6 Pelaporan Penggajian Bagian Human Resource

TABEL II

REQUIREMENT FUNGSIONAL

\begin{tabular}{lll}
\hline No & Aktor & Keterangan \\
\hline 1. & Admin & Mengelola User \\
& & Mengelola Profile Perusahaan \\
& & Mengelola Employee Payslip \\
2. & Admin Human Resource & $\begin{array}{l}\text { Mengelola Payslip Batches } \\
\text { Mengelola Salary Rules }\end{array}$ \\
& & Mengelola Salary Structure \\
3. & Manager Human Resource & Konfirmasi Employee Payslip \\
4. & Financial Controller & Konfirmasi Employee Payslip \\
\hline
\end{tabular}

E. Penyesuaian Odoo 8.0 Modul Human Resource

Pada tahap ini proses penyesuaian dilakukan pada beberapa bagian dari modul Human Resource pada Odoo 8.0 terkait dengan employee payslip payslip batches, dan template print payslip. Proses penyesuaian ini dilakukan melalui penyesuaian berdasarkan pada analisa kebutuhan perusahaan yang sudah dijelaskan dalam Analisis GAP \& FIT \& Proses Bisnis Usulan. Penyesuaian Odoo 8.0 modul Human Resource dilakukan dengan ketentuan menambah atau menghapus field maupun mengubah form. Adapun penjelasan mengenai proses penyesuaian Odoo 8.0 modul human resource dijelaskan pada Tabel III. 
TABEL III

Penyesuaian Odoo 8.0 Modul Human Resource

\begin{tabular}{|c|c|c|c|}
\hline No & $\begin{array}{l}\text { Modul Human } \\
\text { Resource Odoo }\end{array}$ & Penyesuaian & \multirow{2}{*}{ penambahan } \\
\hline \multicolumn{4}{|c|}{ Payroll } \\
\hline \multirow{6}{*}{1.} & \multirow{6}{*}{ Employee Payslip } & \multirow{6}{*}{$\mathrm{V}$} & \\
\hline & & & Yaitu field \\
\hline & & & Department, dan field \\
\hline & & & Job Title \\
\hline & & & disesuaikan \\
\hline & & & kebutuhan perusahaan. \\
\hline 2. & Payslip Batches & $\mathrm{V}$ & $\begin{array}{l}\text { Adanya penghapusan } \\
\text { field. }\end{array}$ \\
\hline 3. & $\begin{array}{l}\text { Template Print } \\
\text { Payslip }\end{array}$ & V & $\begin{array}{l}\text { Adanya } \\
\text { template untuk prin } \\
\text { payslip. }\end{array}$ \\
\hline
\end{tabular}

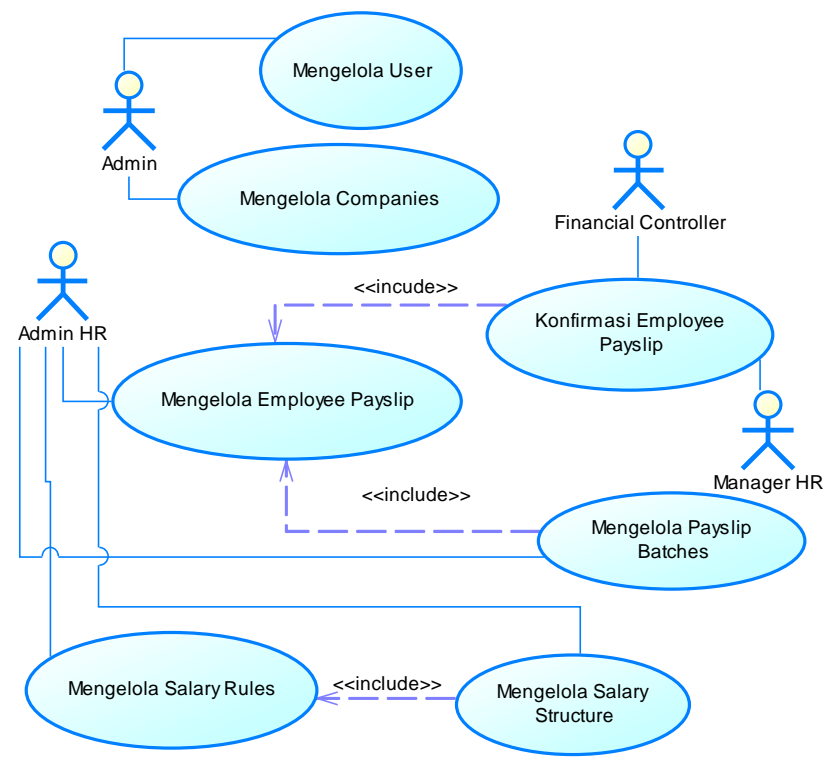

Gambar 7 Use Case Diagram

\section{KESIMPULAN}

Proses bisnis penggajian pada PT. XYZ memiliki 6 proses utama yaitu Proses Gaji Pokok, Proses Tunjangan Tidak Tetap, Proses Peminjaman, Proses Pemotongan Gaji, Proses Tunjangan Hari Raya, dan Proses Pembuatan Laporan Penggajian. Pada praktiknya, mekanisme penggajian yang dilakukan PT. XYZ saat ini masih belum terkomputerisasi dengan baik. Hal tersebut dapat dilihat dari masih ditemukannya kesalahan pada perhitungan, sehingga menyebabkan pelaporan slip gaji karyawan yang tidak sesuai dengan gaji karyawan yang seharusnya diterima. Selain itu keterlambatan pembagian penggajian pun masih ditemukan di PT. XYZ. Konsep Enterprise Resource Planning menjadi sebuah usulan yang diharapkan dapat membantu proses bisnis yang berjalan pada PT. XYZ. Pada Odoo 8.0 Modul payroll terdapat menu employee payslip yang digunakan untuk melakukan perhitungan penggajian, dan pembuatan laporan penggajian yang berisi komponen penggajian, dan total penggajian dengan demikian laporan penggajian bersifat detail. Selain itu modul payroll dapat terintegrasi dengan modul modul ERP lainnya. Hal tersebut diharapkan dapat memberikan penghematan waktu pada proses yang berjalan, khususnya pada proses penggajian di PT. XYZ.

\section{DAFTAR PUSTAKA}

[1] N. Purwandari and W. P. Pamungkas, "Implementasi Modul Human Resource Management Menggunakan Enterprise Resource Planning pada Perusahaan Profit Wills," Sistem Informasi, Institut Teknologi dan Bisnis Kalbis, Jakarta, 2016.

[2] J. Taringan, Enterprise Resource Planning: Dampak Dalam Pendidikan, Profesi Akuntan dan Auditor., Surabaya: Jurusan Akuntansi Fakultas Ekonomi, Universitas Petra, 2008.

[3] S. Wibisono, "Enterprise Resource Planning (ERP) Solusi Sistem Informasi Terintegrasi," Fakultas Teknologi Informasi, Universitas Stikubank Semarang, Semarang, 2015.

[4] R. L. Mathis and J. J. Jackson, Manajemen Sumber Daya Manusia, Jakarta: Akmal, Fauzul. Salemba Empat, 2001.

[5] J. Kendall and K. Kendall, Analisis dan Perancangan Sistem, Jakarta: Indeks, 2010.

[6] E. Monk and B. Wagner, Konsep Enterprise Resource Planning, Buston: Thomson Teknologi Kursus, 2006.

[7] S. Magalhaes, H. Jahankhani and A. Hessami, Global Security, Safety, and Sustainability, Portugal: Springer, 2010.

[8] D. M. T. E. Hariandja, Manajemen Sumber Daya Manusia Pengadaan, Pengembangan, Pengkompensasian, dan Peningkatan Produktivitas Pegawai, Jakarta: PT. Grasindo, 2002.

[9] W. Bangun, Manajemen Sumber Daya Manusia, Jakarta: Erlangga, 2012.

[10] F. Muhammad, "Penerapan Sistem Payroll Berbasis OpenERP pada CV. Huda Jaya Metode Rapid Application Development," Program Studi S1 Sistem Informasi, Fakultas Rekayasa Industri, Universitas Telkom, Bandung, 2015.

[11] W. Niswonger, Reeve and Fees, Accounting: PrinsipPrinsip Akuntansi, Jakarta: Erlangga, 2005.

[12] R. Noe, J. Gerhart and P. Wright, Human Resource Management, fourth edition, New York: Mc GrawHill/Irwin, 2011.

[13] W. Radianto, Memahami Pajak Penghasilan Dalam Sehari: Konsep dan Aplikasi Praktis disesuaikan dengan UU Pajak Pengasilan No.36 Tahun 2008, Yogyakarta: Graha Ilmu, 2010.

[14] A. Pradhana, "Pengembangan Sistem Informasi berbasis Enterprise Resource Planning Modul Sales Management pada Odoo dengan Metode Rapid Application Development di PT. Brodo Ganesha Indonesia," Telkom University, Bandung, 2016.

[15] V. Edison, "Perancangan Modul Penggajian Berbasis 
Odoo," Program Studi Teknik Informatika, Fakultas Teknologi Industri. Universitas Kristen Petra, Surabaya, 2016.

[16] OpenERPIndonesia, Kenapa Harus Menggunakan Open ERP, Jakarta: Graha Ilmu, 2013.

[17] Suhendi, "Perbandingan Modul Payrool Open ERP (Odoo) dengan Modul Payroll Adempiere," Jurusan Sistem Informasi, Sekolah Tinggi Teknologi Terpadu Nurul Fikri, Depok, 2016.

[18] S. Pressman, Rekayasa Perangkat Lunak (Pendekatan Praktisi), Yogyakarta: Andi Ofset, 2002.

[19] E. Kendall and E. Kendall, System Analysis and Design (8th Editon), USA: Prentice Hall, 2010.

[20] A. Hevner, S. Ram, S. March and J. Park, Design Sciene in Information System Research. MIS Quarterly Vol. 28 No. 1, 75-105, 2004.

[21] J. Becker, B. Niehaves and C. Janiesch, "Socio-Technical Perspectives on Design Science in IS Research," Information Systems and eBusiness Management, Vol.9, issue 1, pp. 109 - 131, 2010. 